\title{
Glomus intraradices improved salt tolerance in Prosopis alba seedlings by improving water use efficiency and shoot water content.
}

\section{Agustina A. Scambato ${ }^{1,2}$, Mariela Echeverria ${ }^{1}$, Pedro Sansberro ${ }^{3}$, Oscar A. Ruiz ${ }^{1}$, Ana Bernardina Menéndez ${ }^{1,2 *}$}

\footnotetext{
${ }^{1}$ Instituto Tecnológico de Chascomús (IIB-INTECH) CONICET. Chascomús, Pcia de Buenos Aires, Argentina

${ }^{2}$ Departamento de Biodiversidad y Biología Experimental. Facultad de Ciencias Exactas y Naturales, Universidad de Buenos Aires, Argentina

${ }^{3}$ Instituto de Botánica del Nordeste (IBONE-CONICET), Facultad de Ciencias Agrarias (UNNE), Sargento Cabral 2131, CC: 209, W3402BKG, Corrientes, Argentina.
}

*Corresponding autor: anamen@bg.fcen.uba.ar

Received: 24 August 2010; Accepted: 11 February 2011

\begin{abstract}
The present work was aimed at testing the hypothesis that mycorrhizal Prosopis alba, an economically important tree species worldwide, presents increased salt-tolerance compared with non-mycorrhizal ones and at gaining insight into the possible mechanisms underlying that improvement. For this purpose, a randomized complete block experiment with two factors: mycorrhizal treatments with or without the arbuscular fungus Glomus intraradices and two salinity levels, 0 and $200 \mathrm{mM} \mathrm{NaCl}$ was performed. Plant growth in $P$. alba plants colonized by $G$. intraradices was less affected by salinity than that in non-arbuscular mycorrhizal (AM) plants, indicating that mycorrhizal colonization turned $P$. alba more tolerant to salinity. Photosynthesis was reduced by salinity in non-AM plants but not in AM ones. Salinity caused a significant decrease in mean stomatal conductance and transpiration rate, in mycorrhizal plants, but not in uninoculated ones. In this work, we detected two main mechanisms intervening in the salt tolerance enhancement of $P$. alba by the inoculation with $G$. intraradices: a- maintaining the net photosynthesis level and b- control of the transpiration rate. Taken together, the results suggest that inoculation with $G$. intraradices improves $P$. alba survival rates during the implantation period and seems to be a promising strategy to improve $P$. alba cultivation in saline lands.
\end{abstract}

Key words: photosynthesis, salinity, stomatal conductance, transpiration ratio, proline.

\section{INTRODUCTION}

Soil salinity induces decreases in plant water holding capacity, imbalance of nutrient uptake and ion toxicity towards photosynthesis, resulting in stunted growth and productivity of plants (Munns, 1993; 2002). In the Argentinean Chaco region, a semi-arid to arid zone spanning the provinces of Salta, Formosa, Chaco and Northern Santiago del Estero (Prado, 1993), logging and livestock grazing led to abundance of primary minerals and soluble salts, resulting in extended areas of saline soils (FAO and UNESC0, 1971), with EC values greater than $50 \mathrm{dSm}^{-1}$ (Ragonese, 1951). Several Prosopis tree species, natives to the Chaco and other South America regions, were naturalized in Africa, Australia, and Asia (Pasiecznik et al., 2001). The facts that many of these species are highly tolerant to soil salinity and have a valuable lumber for furniture, forage and medicinal purposes (Rhodes 
and Felker, 1988; Figueiredo, 1990; Felker, 1999; Velarde et. al., 2003; Felker and Guevara, 2003; Cagnolo et al., 2006; Lewis et al., 2009), make them economically attractive to use in governmental programs aimed to recovery wide zones with moderately saline soils (Meloni et al., 2004; Felker et al., 2008). Among them, the argentine mesquite $P$. alba is the most important commercial Prosopis species in Argentina. In addition, this species is able to grow even at the seawater salinity concentration (Velarde et al., 2003). However, growth of $P$. alba showed an approximate $50 \%$ drop in survival at 10 to $25 \mathrm{dSm}^{-1}$ salinity during the early stages of seedling development (Velarde et al., 2003). Therefore, it becomes relevant to find methods increasing salt-tolerance in order to improve the rate of $P$. alba survival during the implantation period. Several authors have shown that arbuscular mycorrhizal (AM) fungi diminish detrimental effects of salinity on plants (Feng et al., 2002). Among the mechanisms intervening on plant growth enhancement by AM fungi are the improvement of water use efficiency (WUE) (Ruiz-Lozano et al., 1996), $\mathrm{K}^{+} / \mathrm{Na}^{+}$ratios (Sannazzaro et al., 2006) and photosynthesis (Mukerji and Chamol, 2003; Al-Karaki, 2006). On the other hand, it has been shown that $P$. alba roots may be colonized by the AM fungus Glomus intraradices (Martin et al., 1994). The present work was aimed at testing the hypothesis that mycorrhizal $P$. alba seedlings present increased salt-tolerance compared with non-AM ones during the first stages of their development and at gaining insight into the possible underlying mechanisms of that improvement.

G. intraradices was propagated in $1 \mathrm{~L}$ pot cultures with soil-perlite (1: 3 V/V) and Sorghum halepense (L.) Pers. (=Andropogon halepensis Brot.) as host for 4 months. $P$. alba seeds were washed under running tap water and surface-sterilized by washing them for 1 min in $10 \%(\mathrm{v} / \mathrm{v})$ $\mathrm{NaOCl}$ and $30 \mathrm{~s}$ in $5 \%(\mathrm{v} / \mathrm{v})$ ethanol. Sterilized $P$. alba seeds were germinated in plastic trays containing sterilized sand. One week-old plants were transferred to 3 I pots filled with a mixture of perlite- vermiculite $(1: 1 \mathrm{~V} / \mathrm{V})$ and inoculated with $5 \mathrm{~g}$ of the AM-fungal inoculum consisting of root fragments with no less than $70 \%$ of their root length infected. Control plants received an equal amount of autoclaved inoculum. Plants of similar height were selected in order to avoid intraspecific growth differences bias. Plants were weekly supplied with nutrient solution containing $1.5 \mathrm{mM} \mathrm{CaCl}, 0.25 \mathrm{mM}$ $\mathrm{MgSO}_{4}, 0.02 \mathrm{mM} \mathrm{KH}_{2} \mathrm{PO}_{4}$ and micronutrients equivalent to $1 / 4$ of Hoagland solution. After two months of pot culture,
AM-inoculated plants showed $60 \%$ of mycorrhizal length colonization. At that moment, half of the non-AM and AM plants were subjected to saline treatment during 4 weeks. For saline treatment, the nutrient solution was supplemented with $200 \mathrm{mM} \mathrm{NaCl}$, which conferred $40 \mathrm{dS} \mathrm{m}^{-1}$ soil electrical conductivity at harvest time. The experiment was performed under controlled environmental conditions $\left(27 \pm 1 / 22 \pm 2{ }^{\circ} \mathrm{C}\right.$ day/night, $14 \mathrm{~h}$ photoperiod, $400 \mu \mathrm{mol} \cdot \mathrm{m}^{-2} \cdot \mathrm{s}^{-1}$ PPFD from fluorescent lamps, 50-55 \% relative humidity).

Plants were harvested and shoot and root dry weights recorded for each individual plant. Assessment of root colonization was performed according to McConigle et al. (1990). Leaf area was determined by using an area meter analyser (LiCor 3000). Foliar gas exchange, water relations, and growth parameters were measured at the end of the experiment. All physiological parameters were determined at midday. Mean stomatal conductance, transpiration and net photosynthesis were measured on intact, fully expanded mature leaves with infrared gas analyzers built into a leaf cuvette in an open-flow gas exchange system (LiCor 6400, USA). The LI6400 light source was used to control photosynthetic photon flux densities (PPFD) at $1500 \mu \mathrm{mol} \mathrm{m}{ }^{-2} \mathrm{~s}^{-1}$. The airstream entering the cuvette was maintained at $350 \mu \mathrm{mol} \mathrm{CO} \cdot \mathrm{mol}^{-1}$ with a computer-controlled $\mathrm{CO}_{2}$ mixing system supplied with the LI-6400. Leaf and air temperatures were measured with thermocouples linked to the LI-6400 computer. Leaf was maintained at desired temperature with a computer controlled Peltier module mounted on the cuvette. The leaf-to-air vapour pressure deficit in the chamber was kept at approximately 1.6 $\mathrm{KPa}$. The WUE was calculated as the mass of fixed $\mathrm{CO}_{2}(\mu \mathrm{mol}$ $\left.\mathrm{CO}_{2} \mathrm{~m}^{-2} \mathrm{~s}^{-1}\right)$ over the mass of transpired $\mathrm{H}_{2} \mathrm{O}\left(\mathrm{mol} \mathrm{H}_{2} \mathrm{O} \mathrm{m}^{-2} \mathrm{~s}^{-1}\right)$. $\mathrm{Na}^{+}$and $\mathrm{K}^{+}$were extracted from oven-dried $\left(70^{\circ} \mathrm{C}\right)$ shoots and roots with $100 \mathrm{mM} \mathrm{HCl}$ and their levels estimated by standard flame photometry (Chen et al., 2001). Proline content was estimated spectrophotometrically by the ninhydrin reaction under conditions described elsewhere (Maiale et al., 2004).

The experiment consisted of a randomized complete block with two factors: 1) mycorrhizal treatments, with $(\mathrm{M}+)$ or without (M-) AM fungus and 2) 0 (S-) and $200(\mathrm{~S}+) \mathrm{mM} \mathrm{NaCl}$. Only one plant was grown in each pot and there were 20 pots (replicates) per treatment. The experiment was performed twice, with similar results. Only results from the most representative experiment are shown. Data were analyzed by ANOVA of two 
factors: salinity (0 and $200 \mathrm{mM}$ ) and symbiotic status (with or without $G$. intraradices).

Salt treatment caused no effect on AM fungal colonization, given that plants presented $70 \%$ of their root length colonized, regardless the saline treatment. However, despite the acknowledged salt tolerance of mature $P$. alba plants, the present study showed a noticeable detrimental effect of salinity on seedling growth, which was in the order of that observed in $P$. juliflora (Hussain and Alshammary, 2008) and $P$. cinerea (Ramoliya et al., 2006). At harvest, dry weights, number of leaves per plant and total leaf area were significantly reduced in salt-stressed plants, either they were or not colonized by G. intraradices (Table 1). Such diminution could be assigned to the extremely high salt content in the soil towards the end of the experiment ( $40 \mathrm{dS} \mathrm{m}^{-1}$ soil electrical conductivity). However, dry biomass and leaf area decreased in a much lower extent in AM plants due to salt treatment, compared with the uninoculated control, and salinity reduced the stem length in non-AM plants, but not in that of AM ones. These findings are consistent with previous reports showing improved plant growth response in mycorrhizal plants under salinity (Feng et al., 2002; Sannazzaro et al., 2006, 2007). A salt-derived reduction in the shoot/root ratio was found in non-AM plants, in accordance with previous results in plants of this species subjected to $600 \mathrm{mM} \mathrm{NaCl}$ (Meloni et al., 2004). In contrast, no significant change in this ratio was observed in salt-treated AM $P$. alba plants. Our results in $P$. alba confirmed that shoot reduction due to salinity is higher than that observed in the roots, as pointed out by Munns and Termaat (1986) and showed that AM colonization reduces organs susceptibility to saline stress, particularly in the case of shoots. Besides, mycorrhizal colonization itself led to increased $P$. alba growth regardless the saline condition, in line with results obtained in $P$. juliflora inoculated with $G$. fasciculatum (Tarafdar and Praveen-Kumar, 1996) and G. aggregatum (Duponnois et al., 2001). High levels of salt-induced defoliation were found in AM and non-AM plants. However, AM plants presented a higher total leaf area than non-AM plants, which along with a lower sensitivity to salinity by net photosynthesis (Table 2), could account for the lower magnitude of salt-induced growth reduction, compared with non-AM ones. It has been suggested that strong reductions in stomatal conductance and transpiration rate represent adaptive mechanisms to cope with excess salt, rather than merely negative consequences of this stress (Flanagan and Jefferies, 1989). Our results showing that upon long-term saline stress, reduced stomatal aperture and transpiration rate (Table 2) corresponded with improved plant growth in mycorrhizal $P$. alba plants (in contrast with non-AM ones) support that view, and put forward that the presence of $G$. intraradices in roots might have activated some mechanism for transpiration control, probably mediated by the enhancement of the absicic acid (ABA, an inhibitor of stomatal opening; Mittlehanser and Van Steveninck, 1969; Jones and Mansfield, 1970; Duan et al., 1996; Goicoechea et al., 1997), given that AM fungi apparently can produce ABA (Esch et al., 1994). In the M+S+ treatment, the sustainment of photosynthetic activity, along with a significantly reduced mean stomatal conductance led to an improved WUE (Table 2), which was 2.0, 2.8 and 1.9 orders of magnitude higher than those of M+S-, M-S+ and M-S- treatments, respectively. These facts denote a lower requirement in the amount of water to produce a unit of plant dry matter in these plants, what eventually might contribute to explain the higher plant biomass found in this treatment, compared with the corresponding non-AM one.

Table 1: Growth parameters and water contents of mycorrhized $(M+)$ and non-mycorrhized (M-) Prosopis alba plants, after exposure to 0 or 200 $\mathrm{mM} \mathrm{NaCl}$ (S- or S+, respectively) during 4 weeks. Standard deviation is shown in italics. Averages with the same letter are not statistically different $(\mathrm{P}<0.05)$.

\begin{tabular}{|c|c|c|c|c|c|c|c|c|}
\hline Parameters & \multicolumn{2}{|c|}{ M-S- } & \multicolumn{2}{|c|}{$\mathrm{M}-\mathrm{S}+$} & \multicolumn{2}{|c|}{$M+S-$} & \multicolumn{2}{|c|}{$\mathrm{M}+\mathrm{S}+$} \\
\hline \multirow{2}{*}{ Total dry weight (g) } & 1.93 & $b$ & 0.44 & c & 3.68 & a & 2.46 & $b$ \\
\hline & 0.43 & & 0.03 & & 0.02 & & 0.24 & \\
\hline \multirow{2}{*}{ Root dry weight (g) } & 0.46 & $b$ & 0.17 & c & 1.11 & a & 0.78 & $b$ \\
\hline & 0.1 & & 0.04 & & 0.12 & & 0.17 & \\
\hline \multirow{2}{*}{ Stem dry weight (g) } & 0.8 & $b$ & 0.2 & c & 1.5 & a & 1.1 & b \\
\hline & 0.21 & & 0.01 & & 0.13 & & 0.09 & \\
\hline \multirow{2}{*}{ Leaf dry weight (g) } & 0.67 & $b$ & 0.062 & c & 1.082 & a & 0.57 & $b$ \\
\hline & 0.21 & & 0.02 & & 0.02 & & 0.12 & \\
\hline \multirow{2}{*}{ Number of leaves per plant } & 12.8 & a & 4.5 & $b$ & 12 & a & 2 & $\mathrm{~b}$ \\
\hline & 0.8 & & 1.5 & & 4.5 & & 0 & \\
\hline \multirow{2}{*}{ Total leaf area $\left(\mathrm{cm}^{2}\right)$} & 157 & $b$ & 23 & c & 256 & a & 148 & $b$ \\
\hline & 55 & & 9.2 & & 24.1 & & 34.2 & \\
\hline \multirow{2}{*}{ Stem length $(\mathrm{cm})$} & 53 & $\mathrm{a}$ & 29 & $b$ & 51 & a & 47 & $a b$ \\
\hline & 6.04 & & 1.73 & & 4.67 & & 3.13 & \\
\hline \multirow{2}{*}{ Shoot/root ratio } & 3.15 & a & 1.63 & $b$ & 2.34 & a & 2.31 & ab \\
\hline & 0.54 & & 0.38 & & 0.39 & & 0.28 & \\
\hline \multirow{2}{*}{ Shoot water content } & 40 & $b$ & 53 & $b$ & 50 & b & 65 & $\mathrm{a}$ \\
\hline & 12 & & 8 & & 8 & & 10 & \\
\hline \multirow{2}{*}{ Root water content } & 63 & a & 60 & a & 68 & a & 66 & $a b$ \\
\hline & 10 & & 12 & & 7 & & 1 & \\
\hline
\end{tabular}


Table 2: Water relations and gas exchange parameters of mycorrhized $(\mathrm{M}+)$ and non-mycorrhized (M-) Prosopis alba plants, after exposure to 0 or 200 $\mathrm{mM} \mathrm{NaCl}$ (S- or $\mathrm{S}+$, respectively) during 4 weeks. Standard deviation is shown in italics. Averages with the same letter are not statistically different $(P<0.05)$

\begin{tabular}{|c|c|c|c|c|c|c|c|c|}
\hline $\begin{array}{l}\text { Water relations and gas } \\
\text { exchange parameters }\end{array}$ & \multicolumn{2}{|c|}{ M-S- } & \multicolumn{2}{|c|}{ M-S+ } & \multicolumn{2}{|c|}{$M+S-$} & \multicolumn{2}{|c|}{$\mathrm{M}+\mathrm{S}+$} \\
\hline \multirow{2}{*}{$\begin{array}{l}\text { Net photosynthesis } \\
\left(\mu \mathrm{mol} \mathrm{CO}^{2} \mathrm{~m}^{-2} \mathrm{~s}^{-1}\right)\end{array}$} & 10.8 & a & 7.4 & $b$ & 11.2 & & 9.9 & $a b$ \\
\hline & 0.9 & & 2.6 & & 0.7 & & 0.7 & \\
\hline \multirow{2}{*}{$\begin{array}{l}\text { Stomatal conductance } \\
\left(\mathrm{mmol} \mathrm{H}_{2} \mathrm{O} \mathrm{m}^{-2} \mathrm{~s}^{-1}\right)\end{array}$} & 0.022 & $\mathrm{a}$ & 0.021 & $a b$ & 0.024 & $\mathrm{a}$ & 0.007 & $b$ \\
\hline & 0.011 & & 0.004 & & 0.011 & & & \\
\hline \multirow{2}{*}{$\begin{array}{l}\text { Transpiration rate } \\
\left(\mathrm{mol} \mathrm{H}_{2} \mathrm{O} \mathrm{m}^{-2} \mathrm{~s}^{-1}\right)\end{array}$} & 0.67 & a & 0.71 & $a b$ & 0.77 & $a$ & 0.22 & b \\
\hline & 0.35 & & 0.15 & & 0.35 & & 0.19 & \\
\hline \multirow{2}{*}{$\begin{array}{l}\text { Water use efficiency } \\
\left(\mu \mathrm{mol} \mathrm{mmol}^{-1}\right)\end{array}$} & 1.89 & b & 1.28 & $b$ & 1.78 & b & 3.66 & $\mathrm{a}$ \\
\hline & 0.31 & & 0.28 & & 0.44 & & 0.71 & \\
\hline
\end{tabular}

The accumulation of various organic metabolites for osmotic adjustment is part of the plant adaptation to the osmotic stress caused by high salt build up in the soil, being proline the most widely distributed osmolyte among plants (Delauney and Verma, 1993; Hasegawa et al., 2000). Our results showed that $P$. alba plants do not accumulate proline in shoots as response to salt stress (data not shown), in accordance with previous results by Meloni et al. (2004). However, the root proline level was increased due to saline treatment in mycorrhizal plants, what could have reduced the water potential of this organ, thus enhancing the water inflow to the plant. Such response, in addition to the reduction in mean stomatal conductance and transpiration rate observed in salinized plants could explain the observed increase in the shoot water content in the AM-plants.

Salinity augmented $\mathrm{Na}^{+}$contents, regardless mycorrhizal treatment, whereas it led to a higher $\mathrm{K}^{+}$accumulation in roots of non-AM plants, and mycorrhizal colonization increased both shoot and root $\mathrm{K}^{+}$contents (data not shown). However, the intense defoliation observed in $P$. alba upon salt-treatment suggests that basipetal re-translocation of $\mathrm{Na}^{+}$excess and a further toxic accumulation of this cation might occur in older leaves, as a mechanism to tolerate salinity (Lessani and Marschner, 1978). Unfortunately, this fact prevents any conclusion linking shoot ion balances and plant growth from our data, since it masks the actual amount of $\mathrm{Na}^{+}$and $\mathrm{K}^{+}$ reaching the shoot.

In this work, we detected two main mechanisms intervening in the salt tolerance enhancement of $P$. alba by the inoculation with $G$. intraradices: a- the net photosynthesis maintenance and b- control of the transpiration rate. Taken together, the information emerged from this work encourages future field experiments to test the hypothesis that inoculation with $G$. intraradices improves $P$. alba survival rates during the implantation period. Moreover, these results could help at designing a technological strategy for the inoculation of arbuscular mycorrhizal fungi at the greenhouse stage, in order to improve $P$. alba implantation in saline fields.

Acknowledgments: The authors are grateful to Ing. Agr. R. Palacios for providing seed material. This work was supported by University of Buenos Aires and the MINCYT, through grants UBCYT x 144 and PICT Start Up 20072034.

\section{REFERENCES}

Al-Karaki, GN (2006) Nursery inoculation of tomato with arbuscular mycorrhizal fungi and subsequent performance under irrigation with saline water. Sci. Hortic. 109: 1-7

Cagnolo, L, Cabido, M, Valladaresa, G (2006) Plant species richness, ecological traits and fragmentation effects in the Chaco Serrano forest from central Argentina. Biol. Conserv. 132: 510-519.

Chen, S, Li, J, Wang, S, Hüttermann, A, Altman, A (2001) Salt, nutrient uptake and transport, and $A B A$ of Populus euphratica: a hybrid in response to increasing soil NaCl. Trees 15: 186-194.

Delauney, AJ, Verma, DPS (1993) Proline biosynthesis and osmoregulation in Plants. Plant J. 4: 215-223.

Duan, X, Neuman, DS, Reiber, JM, Green, CD, Saxton, AM, Augé, RM (1996) Mycorrhizal influence on hydraulic and hormonal factors implicated in the control of stomatal conductance during drought. J. Exp. Bot. 47: 1541-1550.

Duponnois, R, Plenchette, C, Bâ, AM (2001) Growth stimulation of seventeen fallow leguminous plants inoculated with Glomus aggregatum in Senegal. Eur. J. Soil Biol. 37: 181-186.

Esch, H, Hundeshagen, B, Schneiderpoetsch, H, Bothe, H (1994) Demonstration of abscisic acid in spores and hyphae of the arbuscular mycorrhizal fungus Glomus and in the $\mathrm{N}_{2}$-fixing cyanobacterium Anabaena variabilis. Plant Sci. 99: 9-16.

FAO and UNESCO 1971. Soil map of the world 1: 5,000,000 Vol IV, South America(193 pp, UNESCO, Paris,.

Felker, P (1999) An Investment-based Approach to Prosopis Agroforestry in Arid Lands. Ann. Arid Zone 30: 383-385.

Felker, P, Guevara, JC (2003) Potential of commercial hardwood forestry plantations in arid lands - An economic analyses of Prosopis lumber production in Argentina and the United States. Forest Ecol.Manag. 186: 271-286.

Felker, P, Ewens, M, Velarde, M, Medina, D (2008) Initial Evaluation of Prosopis alba Griseb Clones Selected for Growth at Seawater Salinities. Arid Land Res. Manag. 22: 334-345.

Feng, G, Zhang, FS, Li, XL, Tian, CY, Tang, C, Rengel, Z (2002) Improved tolerance of maize plants to salt stress by arbuscular mycorrhiza is related to higher accumulation of soluble sugars in roots. Mycorrhiza 12: 185-190.

Figueiredo, A (1990) Mesquite: History, composition and food uses. Food Technol. 44: 118-129.

Flanagan, LB, Jefferies, RL (1989) Photosyntetic and stomatal response of the halophyte, Plantago maritime $\mathrm{L}$ to fluctuations in salinity. Plant Cell Environ. 12: $559-568$. 


\section{SEEDLINGS BY IMPROVING WATER USE EFFICIENCY AND SHOOT WATER CONTENT}

Goicoechea, N, Antolin, MC, Sánchez-Díaz, M (1997) Gas exchange is related to the hormone balance in mycorrhizal or nitrogen-fixing alfalfa subjected to drought. Physiol. Plantarum 100: 989-997.

Hasegawa, PM, Bressan, RA, Zhu, JK, Bohnert, HJ (2000) Plant cellular and molecular response to high salinity. Annu. Rev. Plant Physiol.Plant Mol.Biol. 51: 463-499.

Hussain, G, Alshammary, SF (2008) Effect of water salinity on survival and growth of landscape trees in Saudi Arabia. Arid Land Res. Manag. 22: 320 - 333.

Jones, RJ, Mansfield, TA (1970) Suppression of stomatal opening in leaves treated with abscisic acid. J. Exp. Bot. 21: 714-719.

Lessani, H, Marschner, H (1978) Relation between salt tolerance and longdistance transport of sodium and chloride in various crop species. Aust. J. Plant Physiol. 5: 27-37.

Lewis, JP, Noetinger, S, Prado, DE, Barberis, IM (2009) Woody vegetation structure and composition of the last relicts of Espinal vegetation in subtropical Argentina. Biod. Conserv. 18: 3615-3628.

Martin, CA, Stutz, JC (1994) Growth of Argentine mesquite inoculated with vesicular-arbuscular mycorrhizal fungi. J. Arbor. 20: 134-139.

Maiale, S, Sanchez, DH, Guirado, A, Vidal, A, Ruiz, OA (2004) Spermine accumulation under salt stress. J.Plant Physiol.161: 35-42.

McConigle TP, Miller, MH, Evans, DH, Fairchild, GL, Swan, JA (1990) A new method which gives and objective measure of colonization of roots by vesiculararbuscular mycorrhizal fungi. New Phytol. 115: 495-501.

Meloni, DA, Gulotta, MR, Martínez, CA, Oliva, MA (2004) The effects of salt stress on growth, nitrate reduction and proline and glycinebetaine accumulation in Prosopis alba. Braz. J. Plant Physiol. 16: 39-46.

Mittlehanser, CJ, Van Steveninck, RFM (1969) Stomatal closure and inhibition of transpiration induced by RS.-abscisic acid. Nature 221: 281-282.

Mukerij, KG, Chamol, BP 2003) Compendium of mycorrhizal research, pp 310 , APH Publisher, New Delhi.
Munns, R (1993) Physiological process limiting plant growth in saline soils some dogmas and hypotheses. Plant Cell Environ. 16: 15-24.

Munns, R (2002) Comparative physiology of salt and water stress. Plant Cell Environ. 25: 239-250.

Munns, R, Termaat, A (1986) Whole-plant responses to salinity. Aust. J.Plant Physiol. 13: 143-160.

Pasiecznikl, NM, Felker, P, Harris, PJC, Harsh, LN, Cruz, G, Tewari, JC, Cadoret, K, Maldonado, LJ (2001) The Prosopis juliflora-Prosopis pallida complex: A Monograph(162 pp HDRA, Coventry, UK

Prado, DE (1993) What is the Gran Chaco vegetation in South America? I. A review Contribution to the study of flora and vegetation of the Chaco V. Candollea 48: 145-172.

Ragonese, AE (1951) La vegetación de la Republica Argentina II. Estudio fitosociológico de las salinas grandes. Rev.Inv. Agr. 5: 1-233.

Ramoliya, PJ, Patel, HM, Joshi, JB, Pandey, AN (2006) Effect of salinization of soil on growth and nutrient accumulation in seedlings of Prosopis cineraria. J. Plant Nut. 29: $283-303$.

Rhodes, D, Felker, P (1988) Mass screening of Prosopis (mesquite) seedlings for growth at seawater salinity concentrations. Forest Ecol. Manag. 24: 169-176.

Ruiz-Lozano, JM, Azcon, R, Gomez, M (1996) Alleviation of salt stress by arbuscular-mycorrhizal Glomus species in Lactuca sativa plants. Physiol. Plantarum 98: 767-772.

Sannazzaro, Al, Ruiz, OA, Alberto, E0, Menéndez, AB (2006) Alleviation of salt stress in Lotus glaber by Glomus intraradices. Plant Soil 285: 279-287.

Tarafdar, JC, Praveen-Kumar (1996) The role of vesicular arbuscular mycorrhizal fungi on crop, tree and grasses grown in an arid environment. J. Arid Environ. 34: $197-203$

Velarde, M, Felker, P, Degano, C (2003) Evaluation of Argentine and Peruvian Prosopis germplasm for growth at seawater salinities. J. Arid Environ. 55: 515-531. 